\title{
Nanotechnology-Based Advancements in Postharvest Management of Horticultural Crops
}

\section{Tarun Kumar Upadhyay ${ }^{1, *}$, V. S. Varun Kumar ${ }^{2}$, Amit Baran Sharangi ${ }^{3}$, Vijay J. Upadhye ${ }^{1}$, Fahad Khan ${ }^{4}$, Pratibha Pandey ${ }^{4}$, Mohammad Amjad Kamal ${ }^{5,6,7}$, Abrar Yasin Baba ${ }^{8}$ and Khalid Rehman Hakeem ${ }^{9}$,}

${ }^{1}$ Department of Biotechnology, Parul Institute of Applied Sciences and Centre of Research for Development, Parul University, Vadodara, 391760, India

${ }^{2}$ Department of Genetics and Plant Breeding, Lovely Professional University, Punjab, Phagwara, 144402, India

${ }^{3}$ Department of Plantation, Spices, Medicinal \& Aromatic Crops, BCKV-Agricultural University, Mohanpur, Nadia, West Bengal, 741252, India

${ }^{4}$ Department of Biotechnology, Noida Institute of Engineering \& Technology, Greater, Noida, 201306, India

${ }^{5}$ West China School of Nursing/Institutes for Systems Genetics, Frontiers Science Center for Disease-Related Molecular Network, West China Hospital, Sichuan University, Chengdu, 610041, China

${ }^{6}$ King Fahd Medical Research Center, King Abdulaziz University, Jeddah, 21589, Saudi Arabia

${ }^{7}$ Enzymoics; Novel Global Community Educational Foundation, Sydney, 201101, Australia

${ }^{8}$ Department of Plant Sciences, Mettu University-Bedele College of Agriculture and Forestry, Bedele Campus, Bedele, 318, Ethiopia

${ }^{9}$ Department of Biological Sciences, Faculty of Science, King Abdulaziz University, Jeddah, 21589, Saudi Arabia

*Corresponding Authors: Khalid Rehman Hakeem. Email: kur.hakeem@gmail.com; Tarun Kumar Upadhyay.

Email: tarun_bioinfo@yahoo.co.in

Received: 26 April 2021 Accepted: 06 August 2021

\begin{abstract}
Horticulture is a branch of Agricultural science where it is defined as the science and art of cultivating and handling fruits, vegetables, ornamental plants and several plants having unique medicinal and aromatic values. Horticultural crops provide farmers with high income and have good export quality, but they have a concern about postharvest losses. Hence, increasing productivity and decreasing post-harvest losses by using scientific studies and techniques like biotechnology and nanotechnology could be the simplest possible solution to the above-mentioned problems. Using nanotechnology which is having the characteristics of nanoparticles is proven to be very useful in science and technological applications. Nanotechnology-based formulations increase the product quality and the shelf life of horticultural products and provide multiple ways of inhibiting the growth and development of microorganisms. It is precisely a new edible packaging coverage (film) that controls the exchange of gases and prevents damage from harmful rays such as ultraviolet radiation to a greater extent. Increasing strength by using nano biosensors for labeling products is considered a fundamental process to automated control of storage products. Postharvest rotting of vegetables is recognized to be an oxidative reaction and microbial deterioration as well. This review will address all such nanotechnology-based advancements for minimizing post-harvest losses of horticultural crops and enhancing the socio-economical progress of growers in particular.
\end{abstract}




\section{KEYWORDS}

Nanotechnology; horticultural crops; post-harvest; fruits; vegetables

\section{Introduction}

Most of the horticultural crops and their products are imperative in our everyday diet. This is because they supply macro-and micronutrients which are needed for maintaining the proper health of individuals and they are highly perishable. The diseases which occur especially after the harvest of the crops are mainly caused by plant pathogenic microorganisms like fungi and bacteria, which cause serious losses during storage and transportation. Many scientific methods are adopted for preservation with physical and chemical methods to avoid crop infestation with diseases and pests, and even the process of ripening after harvesting the crops. For instance, the edible coating is one of the important methods for reducing respiration, and use of metals to stop the attack of diseases and pests cause various postharvest decays of products. Many preservatives are mostly prepared by chemical methods, but silver nanoparticles (SNPs) synthesized from plant extracts of different plants are considered as a recent technology which inhibits the growth of microorganisms, improves water uptake of cut flowers and their vase life, is considered eco-friendly, can be used at a large scale and, most importantly, less harmful compared to their synthetic counterparts. Nanotechnology can be very useful in the spices and aromatic industries and to preserve the aroma, colour and flavour of spices. Using gold nanoparticles-antibody label, contamination of conjugate harmful aflatoxins causing impaired growth can be significantly reduced. Packaging with silver nanoparticles aluminium foils can be useful as it eventually becomes biofilms which allow conservation of the quality of spices, and they can be conserved and served to consumers with the same quality as they have at harvesting [1].

Nanotechnology has become an emerging technology in all fields of science, including medicine and agriculture. Distinct properties of nanomaterials and nanoparticles are also being applied proficiently to transform our farming into a sustainable agriculture in general, and a sustainable horticulture in particular; this is the result of minimizing postharvest diseases of vegetables and fruits at the scientific and industry levels [2]. Postharvest losses in fruits and vegetables are from $4.58 \%$ to $15.88 \%$. About $10 \%-15 \%$ of shrink and decay on fresh fruits and vegetables lower their market value and consumer acceptability. Among these losses, $18 \%$ comes from animals and pests, and $16 \%$ are due to diseases where $72 \%-85 \%$ of the losses are caused by fungi [3]. The economic losses are mainly due to fungal diseases. Postharvest production is variable and ranges from $30 \%-50 \%$ which mainly depends on good agricultural or cultural practices and locations [4-6]. The Food and Agriculture Organization identified that $33 \%$ of the food delivered worldwide for human consumption is lost after crop harvesting [7]. These losses were distributed throughout the production network as a result of pathogen-initiated diseases that cause most of the food wastage. Minimizing these losses will ultimately increase their supply and reduce the overall cost.

\section{Controlling Growth and Development of Microorganisms}

There are many pathogens causing diseases but an important postharvest pathogen around the world is Botrytis cinerea which causes the grey mould disease. It causes decay on a large number of economically important horticultural crops, especially on vegetables and fruits, and even on ornamental flowers like marigolds. It affects the flowers at the pre- and postharvest stages. It is also a major problem on long distance transport and storage. This pathogen infects leaves, stems, flowers, and fruits, either by primary or secondary infection [8]. 
There are many benefits of using edible coatings which can eventually reduce water loss, slow the rate of ripening, reduce chilling and mechanical injury, reduce decay and add shining to the coated products. Edible coatings can be used as antimicrobial composites, antioxidants or anti-ripening compounds which ultimately induce changes in flavour due to late ripening or result of anaerobic changes. Coatings can be made from proteins, lipids, polysaccharides or can be made from those biomacromolecules [9]. Different edible coatings can be used on fruits and vegetables as shown in Table 1.

Chitosan is a biopolymer derived from chitin (a polysaccharide constituent of crustacean shells). It also exhibits antimicrobial properties reduce postharvest decay of Horticultural crops [10-13]. The application of Chitosan has been widely used to control pre-harvest and postharvest diseases. It can also control the quality of fruits and vegetables as it have low toxicity, is safe for human consumption and is environmental friendly [14,15]. Chitosan also improves the resistance of tomato fruit against grey mould disease caused by $B$. cinerea, and is highly promising as a natural composite to partially substitute the utilization of synthetic fungicides. When the coating of chitosan of 102.4-370 nm diameter was combined with $1 \%$ of gum arabic and applied on banana fruit, the ripening process of fruits is reduced and the shelf life is increased for a few days compared to uncoated banana [16].

A nanotechnological coating based on pullulan and polymeric nanocapsules of a range of $153.9 \mathrm{~nm}$ containing an essential oil extracted from thyme (Thymus vulgaris L.) was applied to increase the shelf life of table grapes. Grapes coated with the formulated nanocapsules maintained their colour, firmness, and total soluble salts (TSS) content for a longer period compared to untreated grapes. Coated grapes had a lower incidence of gray mould compared to untreated ones. The nanocapsule coating avoided quicker evaporation of volatile compounds and increased their persistence on the grape surfaces, thus delaying ripening and extending the shelf life [17] as shown in Fig. 1.

Colletotrichum gloeosporioides is a serious pathogen in various horticultural crops like mango and guava after the harvest of a crop. Silver nanoparticle composite with size 10-15 nm inhibited fungal growth by especially inhibiting the conidial germination [18].

A clay-chitosan nanocomposite was prepared against Penicillium digitatum which attacked 'Valencia Late' sweet orange. It showed complete inhibition of the pathogen and suppressed branching of hyphae at a concentration of $20 \mu \mathrm{g} \cdot \mathrm{mL}^{-1}$ [19].

Table 1: Different edible coatings used on fruits and vegetables

\begin{tabular}{lllc}
\hline Edible coating & $\begin{array}{l}\text { Fruits/ } \\
\text { vegetables }\end{array}$ & Action & References \\
\hline $\begin{array}{l}\text { Chitosan/ } \\
\text { Tripolyphosphate (TPP) }\end{array}$ & Banana & Slower rate of ripening process & {$[20]$} \\
$\begin{array}{l}\text { Gelatin-Fiber/titanium } \\
\text { dioxide(TiO } 2)\end{array}$ & Melon & $\begin{array}{l}\text { Effective for controlling mold and yeast population } \\
\text { growth }\end{array}$ & {$[21]$} \\
$\begin{array}{l}\text { Gelatin-Chitosan/ } \\
(\text { Ag/ZnO) }\end{array}$ & $\begin{array}{l}\text { Okra/lady's } \\
\text { finger }\end{array}$ & $\begin{array}{l}\text { Antimicrobial polyethylene packaging for the } \\
\text { preservation of quality of vegetable }\end{array}$ & {$[22]$} \\
$\begin{array}{l}\text { Chitosan-methyl } \\
\text { Cellulose/Silica }\left(\mathrm{SiO}_{2}\right)\end{array}$ & Loquat fruit & Effective in enhancing chilling tolerance & {$[23]$} \\
$\begin{array}{l}\text { Chitosan/silica } \\
\text { nanocomposite }\end{array}$ & Table grapes & Antifungal & {$[24]$} \\
\hline
\end{tabular}




\begin{tabular}{|c|c|c|c|}
\hline Edible coating & $\begin{array}{l}\text { Fruits/ } \\
\text { vegetables }\end{array}$ & Action & References \\
\hline Gelatin/Kafirin & Vegetables & Rate of respiration and reducing water loss & {$[25]$} \\
\hline Silica nanoparticles & Grapes & Antifungal & {$[26]$} \\
\hline $\begin{array}{l}\text { Nanocomposite-Aloe } \\
\text { vera gel }\end{array}$ & Mango & Increasing titratable acid and elongation & {$[27]$} \\
\hline $\begin{array}{l}\text { Microencapsulated } \\
\text { ascorbic acid }\end{array}$ & Guava & Decrease the respiration rate & [28] \\
\hline $\mathrm{ZnO}$ nanoparticles & Cucumber & $\begin{array}{l}\text { Carotene, zinc and iron increase in cucumber } \\
\text { observed }\end{array}$ & [29] \\
\hline Se nanoparticles & Tomato & $\begin{array}{l}\text { Tomato yield increased by } 21 \% \text { with } 10 \mathrm{mg} / \mathrm{L} \mathrm{Se} \\
\text { nanoparticles }\end{array}$ & {$[30]$} \\
\hline Chitosan nanoparticles & Grapes & $\begin{array}{l}\text { Delayed the ripening process, increased moisture } \\
\text { retention }\end{array}$ & {$[31]$} \\
\hline $\begin{array}{l}\text { Chitosan-silver NPs } \\
\text { composite }\end{array}$ & Mango & $\begin{array}{l}\text { Higher antifungal against } \\
\text { Colletotrichumgloeosporioides }\end{array}$ & [32] \\
\hline
\end{tabular}

\subsection{Silver Nanoparticle for Increasing Vase Life of Cut Flowers}

Cut flowers are used to show gratitude, affection and many people used them to express emotion on numerous occasions. The two most important aspects of a cut flower are vase life and quality. The customers get satisfied and repeat the purchase for these appealing factors throughout the world in almost all the ornamental markets. When cut flowers are harvested they do not have a prolonged shelf life, due to interrupted inflow of water because of microbial proliferation.

Various nanotechnological products, like Nano-silver, are used as anti-microbial agents and ethylene inhibitors. Using Silver Nanoparticles for extending the vase life of cut flowers not only inhibit the growth of bacteria but also enter into the vascular tissues of the stem and limits synthesis of ethylene which suppresses ethylene synthesising genes ACO1 (Musa acuminata oxidase 1) and ACS1 (Musa acuminata synthase 1). Moreover, it also increases the uptake of the solution thereby ultimately increasing the vase life of cut flowers [33].

The use of this preservative solution for extending the vase life of cut flowers has been widely applied. These silver nanoparticles are harmless, easy to apply with no side effects and with high stability [34]. Different concentrations of silver nanoparticles are having various applications in improving and maintaining the quality of cut flowers (Table 2).

Table 2: Silver nanoparticles concentrations for different cut flowers to improve vase life

\begin{tabular}{|c|c|c|c|c|}
\hline Cut flower & $\begin{array}{l}\text { Application } \\
\text { method }\end{array}$ & $\begin{array}{l}\text { Silver nanoparticles } \\
\text { concentration }\end{array}$ & Improved results & References \\
\hline Carnation & $\begin{array}{l}\text { Vase } \\
\text { solution }\end{array}$ & $5 \mathrm{mg} \mathrm{L}^{-1}$ & $\begin{array}{l}\text { Suppressed ethylene } \\
\text { synthesis }\end{array}$ & [35] \\
\hline Chrysanthemum & $\begin{array}{l}\text { Pulse } \\
\text { treatment }\end{array}$ & $10 \mathrm{mg} \mathrm{L}^{-1}$ & $\begin{array}{l}\text { Reduced vascular occlusion } \\
\text { and prevented water stress }\end{array}$ & [36] \\
\hline
\end{tabular}




\begin{tabular}{|c|c|c|c|c|}
\hline Cut flower & $\begin{array}{l}\text { Application } \\
\text { method }\end{array}$ & $\begin{array}{l}\text { Silver nanoparticles } \\
\text { concentration }\end{array}$ & Improved results & References \\
\hline Gerbera & $\begin{array}{l}\text { Pulse } \\
\text { treatment }\end{array}$ & $10 \mathrm{mg} \mathrm{L}^{-1}$ & $\begin{array}{l}\text { Maintained water content and } \\
\text { hydraulic conductance }\end{array}$ & [37] \\
\hline Lisianthus & $\begin{array}{l}\text { Vase } \\
\text { solution }\end{array}$ & $40 \mathrm{mg} \mathrm{L}^{-1}$ & Increasing quality and vase life & {$[38]$} \\
\hline $\begin{array}{l}\text { Mokara Red } \\
\text { orchid flower }\end{array}$ & $\begin{array}{l}\text { Pulse } \\
\text { treatment }\end{array}$ & $5 \mathrm{mg} \mathrm{L}^{-1}$ & Increasing the vase life & {$[39]$} \\
\hline
\end{tabular}

\subsection{Methods for Silver Nanoparticles Synthesis}

Nanoparticles are generally prepared using chemical methods which may be difficult in separation and purification from nanoemulsions and their utilization on a large number of surfactants. Similarly, nanoparticles can be prepared using plant extracts which will be eco-friendly, and usage of toxic chemical substances can be reduced [40]. Silver Nanoparticles can be synthesized on a very large scale compared to chemically prepared Silver Nanoparticles on a small scale. Different Silver Nanoparticles were prepared using different plant extracts which are shown in Tables 3 and 4. Basil, banana, geranium leaves, pomegranate, Aloe vera, Centella asiatica, Murraya koenigii, Alternanthera sessilis, Piper nigrum and many other crops have been reported in this context [41]. SNPs prepared using both plant extracts and microbial synthesis are very eco-friendly in nature. The SNPs act as antimicrobial agents by reducing infection from bacteria which blocks water transportation through the stem. SNPs prepared with green synthesis will be easy for application and this will have a large surface area and good stability. All these properties make SNPs an excellent medium for the preservation of cut flowers, medicinal and aromatic plants. Spices contaminated by aflatoxin can also be safeguarded by using nanoparticles to avoid contamination.

Table 3: Plant-derived metallic nanoparticles and their applications

\begin{tabular}{|c|c|c|c|c|c|c|c|}
\hline Plants used & Nanoparticles & $\begin{array}{l}\text { Parts of } \\
\text { plant }\end{array}$ & Size $(\mathrm{nm})$ & Shapes & $\begin{array}{l}\text { Plant metabolites } \\
\text { involved in } \\
\text { bioreduction }\end{array}$ & $\begin{array}{l}\text { Pharmacological } \\
\text { applications }\end{array}$ & References \\
\hline Acalyphaindica & $\mathrm{Ag}, \mathrm{Au}$ & Leaves & $20-30$ & Spherical & $\begin{array}{l}\text { Quercetin, plant } \\
\text { pigment }\end{array}$ & Antibacterial & [42] \\
\hline Aloe vera & $\mathrm{In}_{2} \mathrm{O}_{3}$ & Leaf & $5-50$ & Spherical & Biomolecules & Optical properties & [43] \\
\hline Alternantherasessilis & $\mathrm{Ag}$ & Whole & 40 & Spherical & $\begin{array}{l}\text { Amine, carboxyl } \\
\text { groups }\end{array}$ & $\begin{array}{l}\text { Antioxidant, } \\
\text { antimicrobial }\end{array}$ & {$[44]$} \\
\hline Andrographispaniculata & $\mathrm{Ag}$ & Leaves & $67-88$ & Spherical & $\begin{array}{l}\text { Alkaloids, } \\
\text { flavonoids }\end{array}$ & $\begin{array}{l}\text { Hepatocurative } \\
\text { activity }\end{array}$ & [45] \\
\hline Boswelliaserrata & $\mathrm{Ag}$ & Gum & $7-10$ & Spherical & Proteins, enzymes & Antibacterial & [46] \\
\hline Carica papaya & $\mathrm{Ag}$ & Fruit & 15 & Spherical & $\begin{array}{l}\text { Hydroxyl flavones, } \\
\text { catechins }\end{array}$ & Antimicrobial & {$[47]$} \\
\hline Cassia fistula & $\mathrm{Au}$ & Stem & $55-98$ & Spherical & Hydroxyl groups & Antihypoglycemic & [48] \\
\hline Cinnamomumzeylanicum & $\mathrm{Ag}$ & Leaves & 45 & Spherical & $\begin{array}{l}\text { Water-soluble } \\
\text { organics }\end{array}$ & Antibacterial & {$[49]$} \\
\hline
\end{tabular}




\begin{tabular}{|c|c|c|c|c|c|c|c|}
\hline Plants used & Nanoparticles & $\begin{array}{l}\text { Parts of } \\
\text { plant }\end{array}$ & Size (nm) & Shapes & $\begin{array}{l}\text { Plant metabolites } \\
\text { involved in } \\
\text { bioreduction }\end{array}$ & $\begin{array}{l}\text { Pharmacological } \\
\text { applications }\end{array}$ & References \\
\hline Citrulluscolocynthis & $\mathrm{Ag}$ & Calli & $5-70$ & Triangle & Polyphenols & $\begin{array}{l}\text { Antioxidant, } \\
\text { anticancer }\end{array}$ & {$[50]$} \\
\hline Citrus sinensis & $\mathrm{Ag}$ & Peel & 35 & Spherical & $\begin{array}{l}\text { Water-soluble } \\
\text { compounds }\end{array}$ & Antibacterial & {$[51]$} \\
\hline Dilleniaindica & $\mathrm{Ag}$ & Fruit & $11-24$ & Spherical & Biomolecules & Antibacterial & {$[52]$} \\
\hline Dioscoreabulbifera & $\mathrm{Ag}$ & Tuber & $8-20$ & $\begin{array}{l}\text { Rod, } \\
\text { triangular }\end{array}$ & $\begin{array}{l}\text { Diosgenin, } \\
\text { ascorbic acid }\end{array}$ & Antimicrobial & {$[53]$} \\
\hline Euphorbia prostrata & $\mathrm{Ag}$ & Leaves & 52 & $\begin{array}{l}\text { Rod, } \\
\text { spherical }\end{array}$ & $\begin{array}{l}\text { Proteins, } \\
\text { polyphenols }\end{array}$ & Antiplasmodial & {$[54]$} \\
\hline Lippiacitriodora & $\mathrm{Ag}$ & Leaves & $15-30$ & Spherical, & $\begin{array}{l}\text { Isoverbascoside } \\
\text { compound }\end{array}$ & Antimicrobial & {$[55]$} \\
\hline Menthapiperita & $\mathrm{Au}, \mathrm{Ag}$ & Leaves & $90-150$ & Spherical & Menthol & Antibacterial & {$[56]$} \\
\hline Mirabilis jalapa & $\mathrm{Au}$ & Flowers & $\sim 100$ & Spherical & Polysaccharides & Antimicrobial & {$[57]$} \\
\hline H. canadensis & $\mathrm{Ag}$ & Whole & 113 & Spherical & Phenolics, proteins & Cytotoxicity & {$[58]$} \\
\hline Iresineherbstii & $\mathrm{Ag}$ & Leaves & $44-64$ & Cubic & $\begin{array}{l}\text { Biomolecules } \\
\text { phenolic } \\
\text { compounds }\end{array}$ & $\begin{array}{l}\text { Biological } \\
\text { activities }\end{array}$ & {$[59]$} \\
\hline Meliaazedarach & $\mathrm{Ag}$ & Leaves & 78 & Irregular & $\begin{array}{l}\text { Tannic acid, } \\
\text { polyphenols }\end{array}$ & Cytotoxicity & {$[60]$} \\
\hline Tinosporacordifolia & $\mathrm{Ag}$ & Leaves & 34 & Spherical & $\begin{array}{l}\text { Phenolic } \\
\text { compounds }\end{array}$ & Antilarvicidal & {$[61]$} \\
\hline $\begin{array}{l}\text { Trigonella- } \\
\text { foenumgraecum }\end{array}$ & $\mathrm{Au}$ & Seed & $15-25$ & Spherical & Flavonoids & Catalytic & {$[62]$} \\
\hline Withaniasomnifera & $\mathrm{Ag}$ & Leaves & $5-40$ & $\begin{array}{l}\text { Irregular, } \\
\text { spherical }\end{array}$ & $\begin{array}{l}\text { Methyl 7- } \\
\text { oxooctadecanoate }\end{array}$ & Antimicrobial & {$[63]$} \\
\hline
\end{tabular}

Source: Kuppusamy et al. [41].

Apart from the green synthesis of Silver Nanoparticles, they can also be prepared using biological substances likebacterial species (e.g., Alcaligenes faecalis). These were effective in suppressing the growth of microbes, decreased the production of ethylene, and reduced stomatal conductance which showed improved vase life of roses [64].

Table 4: Different Plant extracts used for the preparation of silver nanoparticles

\begin{tabular}{|c|c|c|c|}
\hline Flower & Plant extract & Improved quality & References \\
\hline Rose & Saffron petal extracts & $\begin{array}{l}\text { Inhibited the growth of } \\
\text { Bacillus and Pseudomonas }\end{array}$ & {$[65]$} \\
\hline Carnation & Saffron petal extracts & $\begin{array}{l}\text { Increasing water uptake and decreased } \\
\text { leakage of ions from petal tissues }\end{array}$ & {$[66]$} \\
\hline Chrysanthemum & Mexican tea & $\begin{array}{l}\text { Promoted flower opening and } \\
\text { extended vase } \\
\text { Life }\end{array}$ & {$[67]$} \\
\hline Gerbera & $\begin{array}{l}\text { Carvacrol essential oil extracted } \\
\text { from oregano (Origanum vulgare) }\end{array}$ & Antimicrobial & {$[68]$} \\
\hline
\end{tabular}




\subsection{Applications of Nanotechnology in Aromatics and Spices Industries}

Spices are the best products used for food flavouring as they enhance flavour, taste and also change food colour and prolong the shelf life of foods by suppressing microbes and protecting food deterioration. Aflatoxins are mycotoxins produced by the fungi Aspergillus flavus and Aspergillus parasiticus. These toxins may cause impaired growth, reduce immunity in the body and its harshness may also cause liver cancer. The conjugated antibodies and NPs were used as labels for identifying aflatoxins B and G and Aflatoxin M1 using gold NPs-antibody label conjugate [69].

Nanocoatings containing metallic particles with NPs or biopolymers offer various ways of colour enhancement, extending shelf life, reduction of browning, enhancing flavour, improving availability of anti-oxidants from spices, etc. The quality of spices and aromatic products can be improved using nanotechnology. Spice lumping is a serious problem in reducing shelf life and market quality. The NPs Nano $\mathrm{SiO}_{2}$, Nano $\mathrm{Ca}_{2} \mathrm{SO}_{4} \mathrm{Si}$, Nano Sodium aluminosilicate and dicalcium phosphate are having a wide range of scope in reducing the lumping and free-flowing nature of spices [70].

\section{Nanotechnology for Packaging}

Nanotechnology has the potential to generate new fruit packaging. The new technology of nano-packing materials with lower relative humidity, oxygen transmission rate, and high strength was synthesized by blending polyethylene with nano-powder (nano-Ag, kaolin, anatase $\mathrm{TiO}_{2}$, mineral $\mathrm{TiO}_{2}$ ), and it enhanced the preservation quality of fruits throughout storage at $40^{\circ} \mathrm{C}$ [71]. Nano-packaging can maintain the sensory properties and chemical and physiological qualities of strawberry fruits at a better level compared with the conventional packing (polyethene bags) [72]. Also, nano packaging is more efficient than the normal polyethene packaging concerning a reduction in decay rate, and anthocyanin and malondialdehde contents (Table 5).

Table 5: Comparison of packing with nano packing and conventional packing and their effect on reduction in decay rate, Anthocyanin and Malondialdehde contents

\begin{tabular}{lll}
\hline Contents & Nano packaging & Conventional packaging \\
\hline Decay rate & $16.7 \%$ & $26.8 \%$ \\
Anthocyanin & $26.3 \mathrm{mg} / 100 \mathrm{~g}$ & $31.9 \mathrm{mg} / 100 \mathrm{~g}$ \\
Malondialdehde & $66.3 \mathrm{micromol} / \mathrm{g}$ & $75.4 \mathrm{micromol} / \mathrm{g}$ \\
\hline
\end{tabular}

Polyphenoloxidase (PPO) and Pyrogallic acid oxidase (POD) activities were considerably lower in nano-packing than conventional management. These showed that nano-packaging may offer a beneficial role to enhance the preservation quality of the fruits throughout extended storage [73].

In the United States, apples are marketed with a waxy coating, which prevents fruit from loss of moisture content and shrinking. Currently, edible coatings are $5 \mathrm{~nm}$ for fruit, vegetables, and baked products. The edible coating blocks gas exchange, prevents water loss, maintains colour, flavours, and antioxidants, and can preserve products even after the opening of packing [74]. Fuji apples that were coated with Nano$\mathrm{SiOx} /$ chitosan composite preservation agents had a better quality than without coating [75]. Green tea which was packed with nano-packing had better maintenance of vitamin $\mathrm{C}$, chlorophyll, polyphenols and amino acids than compared with normal packing [76]. As mentioned above for various uses, nano packaging is also exploited for food packaging as shown in Table 6. 
Packaging of spices is a complex issue as the technique should not only enhance shelf life but also retain its aroma, colour, flavour and reduce infection of microbes. Electrochemical anodisation was used to produce cylindrical nanopores between 15 and $100 \mathrm{~nm}$ diameter on an aluminium surface of packaging foil. These surfaces were then incubated with cultures of $E$. coli and Listeria innocua. The surfaces covered with nanopores of 15-25 nm diameter significantly inhibited both attachment and biofilm formation which are safe for spices packaging [77].

Table 6: Applications of nanomaterials in food packaging

\begin{tabular}{|c|c|c|c|}
\hline $\begin{array}{l}\text { Nanomaterial packaging } \\
\text { material }\end{array}$ & $\begin{array}{l}\text { Fruits and vegetables } \\
\text { used for packaging }\end{array}$ & Properties of packaging & References \\
\hline $\mathrm{TiO}_{2}$-Chitosan & Grapes & $\begin{array}{l}\text { It acts as a preservative and prevents entry } \\
\text { of microbes }\end{array}$ & [78] \\
\hline Ag-Cellulose films & Tomato & Prevents bacterial growth and infection & [79] \\
\hline TiO-Polyacrylonitrile & Tomato & Reduces ethylene rate & {$[80]$} \\
\hline ZnO-Chitosan & Apple and mango & Antioxidant and prevents microbes attack & [81] \\
\hline
\end{tabular}

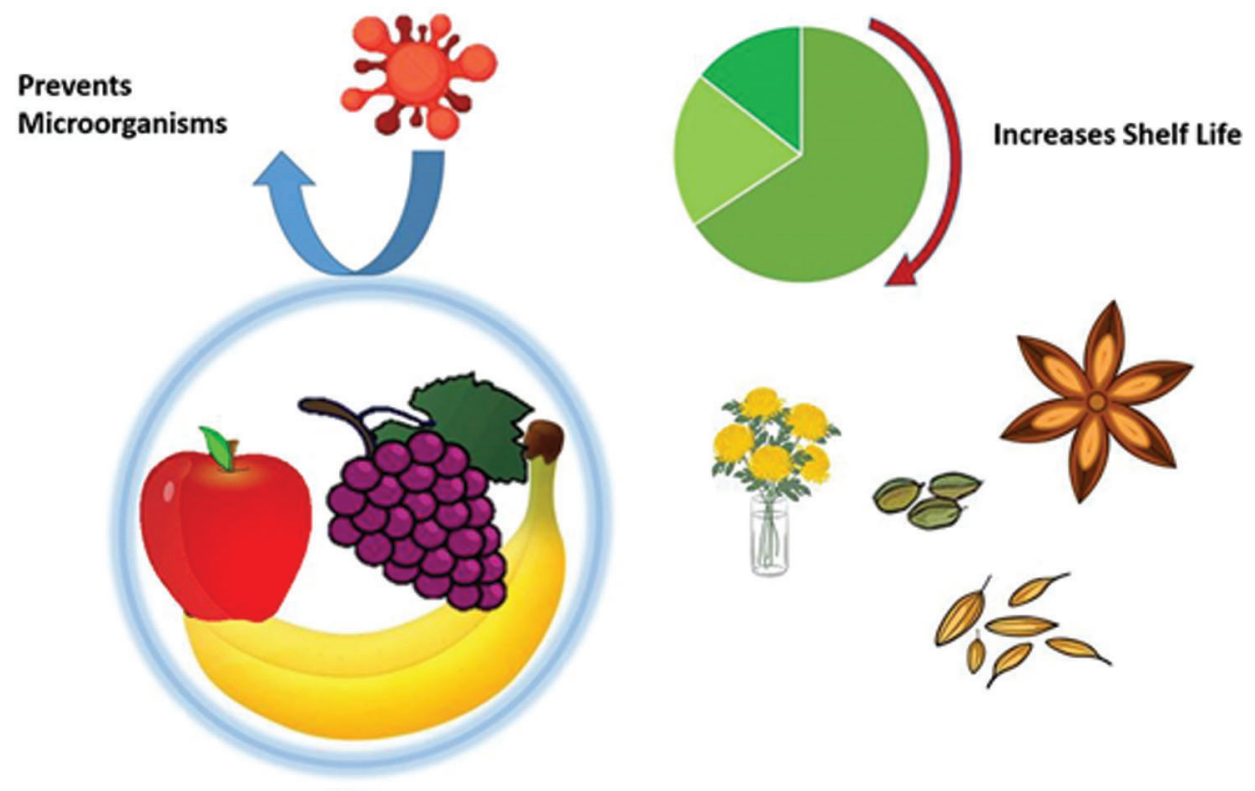

Figure 1: Nanotechnological role inedible coatings of horticultural crops

\subsection{Nanoemulsions}

An emulsion is a combination of two or more solutions that do not combine easily. Nanoemulsions are nano-sized emulsions that lie in the range of nanoscale, which are manufactured for improving the delivery of active pharmaceutical ingredients. These are the thermodynamically stable isotropic system in which two immiscible liquids are mixed to form a single-phase using an emulsifying agent, i.e., surfactant and co-surfactant. 
Using Nanoemulsion coating of Carnauba wax of $42 \mathrm{~nm}$ diameter (also called Brazil wax and palm wax) is an accepted proposition. This wax was extracted from leaves of the carnauba palm (Copernicia prunifera) at $2.4 \%$ and it was applied on Papaya fruit. The fruits were stored for 9 days at $22^{\circ} \mathrm{C}$ and a relative humidity of $60 \%-70 \%$; it was found that the fruits showed a reduced decaying and loss of mass [82]. Various nanoemulsions are used on fruits for protecting them from deterioration and prevention from microbes attack as shown in Table 7.

Nanolaminate is a very thin food-grade film (ranges from 1-100 nm/layer) with physically or chemically bonded dimensions [83]. Nanolaminate has many advantages in preparing edible films. Edible films are present on numerous horticultural produce and chocolate, toffees, baked goods and French fries [84]. These films protect foods from loss of moisture, lipids, and gases. These films improve the textural properties of fruits and also retain colour, flavour, antioxidant and nutrient content.

Table 7: Different Nanoemulsions used for edible coatings of different fruits to enhance shelf-life

\begin{tabular}{llll}
\hline Fruits & Nanoemulsion & Method of emulsion & References \\
\hline Red Delicious-Apple & Tocopherol/nopal mucilage nanoemulsion & Encapsulant & {$[85]$} \\
GolabKohanz-Apple & Chitosan-nanoemulsion & Coating & {$[86]$} \\
Banana & Chitosan-Nanoemulsion & Coating & {$[87]$} \\
Papaya & Chitosan-Nanoemulsion & Coating & {$[88]$} \\
Papaya & Wax Nanoemlusion & Coating & {$[89]$} \\
\hline
\end{tabular}

\section{Multiple Chips (Nanobiosensors) for Labelling of the Products}

Nanotechnology-based biodegradable sensors in the form of small chips such as electronic tongue technology sensors are recently being utilized widely in food products. It changes the colour of the product when its $\mathrm{pH}$ changes because of spoilage. A "Release on command" nanobioswitch (Netherlands) operates the preservative packaging [90]. Biological molecules like sugars or proteins are used for nanostructures as biosensors on food [91]. These biosensors (1) function as detectors of food pathogens and other microbes, and (2) act as a device to trace food products. Nanotechnology is also useful in encapsulation systems for protection against environmental factors. Further, it can be used in the design of food ingredients such as flavour and antioxidants [92]. The main objective is to improve the functionality of such ingredients while minimizing their concentration. As the infusion of these innovative ingredients gets into foods, it gains more popularity [93]. It will also occur the greater exploration of delivery controlled release systems for nutraceuticals [94].

Nanomaterials shown are having numerous optical and electrochemical properties in different hot and cold drinks, juices and oils (Table 8). Different biosensors are utilized based on Nanomaterials used in various agriculture and food industries. There are many applications of nano-biosensors which include virus recognition using antibody sensor arrays on self-assembled nanoscale block copolymer Patterns, and the detection of food-borne toxins using multifunctional nanoparticles. It is also used in the detection of pore-forming toxins, molecularly imprinted polymers for plant and insect virus recognition. 
Table 8: Applications of Nanobiosensors in different food materials

\begin{tabular}{|c|c|c|c|c|c|}
\hline $\begin{array}{l}\text { Type of sensor } \\
\text { used in food }\end{array}$ & $\begin{array}{l}\text { Material used for } \\
\text { detection }\end{array}$ & $\begin{array}{l}\text { Food } \\
\text { product } \\
\text { used }\end{array}$ & Nanoparticle & Functions & References \\
\hline \multirow[t]{2}{*}{$\begin{array}{l}\text { Electrochemical } \\
\text { method }\end{array}$} & $\begin{array}{l}\text { Tert- } \\
\text { butylhydroquinine }\end{array}$ & $\begin{array}{l}\text { Cooking } \\
\text { oils }\end{array}$ & $\begin{array}{l}\text { Au nanoparticles } \\
\text { electro deposited } \\
\text { on graphene } \\
\text { ribbons }\end{array}$ & $\begin{array}{l}\text { Conductivity } \\
\text { enhancements due to } \\
\text { growth in the surface } \\
\text { region on the target sites }\end{array}$ & [95] \\
\hline & $\begin{array}{l}\text { Leftover } \\
\text { pesticides }\end{array}$ & $\begin{array}{l}\text { Potato } \\
\text { and } \\
\text { onion }\end{array}$ & $\begin{array}{l}\mathrm{TiO}_{2} \\
\text { nanostructure }\end{array}$ & $\begin{array}{l}\text { Upgraded } \\
\text { electrochemical } \\
\text { properties and } \\
\text { conductivity }\end{array}$ & [96] \\
\hline \multirow[t]{2}{*}{ Optical method } & Gallic acid & $\begin{array}{l}\text { Clove } \\
\text { and } \\
\text { green tea } \\
\text { extracts }\end{array}$ & $\begin{array}{l}\text { Au nanotubes } \\
\text { bismuth-based }\end{array}$ & $\begin{array}{l}\text { Morphological changes } \\
\text { were observed }\end{array}$ & [97] \\
\hline & $\begin{array}{l}\text { Antibiotics } \\
\text { (Sulfonamides) }\end{array}$ & Honey & Au nanoparticles & $\begin{array}{l}\text { Surface plasmon } \\
\text { resonance properties }\end{array}$ & [98] \\
\hline
\end{tabular}

\subsection{Constraints}

Despite numerous potential uses of nanotechnology in various fields like medical, agriculture, space research technology, etc., there are certain safety concerns with the use of this technology in the environment which still need to be discussed. Some key restrictions and threats related to the agricultural application of nanotechnology are as follows:

1. The existing knowledge on nanotechnology is still at the beginning stage; consequently, it is not possible to forecast the effect of the nanoparticles on human health and the environment [99].

2. Interaction of nanoparticles with non-target sites often leads to certain environmental and health issues [100].

3. Higher production costs.

4. Developments in the agricultural sector are significantly limited due to the low investment in research fields, and provision of low-quality training, etc.

5. Public is not aware of many applications of nanotechnology. This is because people generally follows traditional practices and doesn't accept the new technologies.

6. The various products of nanotechnology and their commercial utilization in various fields still need to be controlled just to make sure that they are safe to use in these areas.

Hence, the appropriate knowledge of these nanomaterials and their possible contacts in the human body is always needed to be examined before their commercial application.

\section{Conclusions}

Nanomaterials showed a vital potential in postharvest technology management. Simple postharvest practices like appropriate early harvest, clean washing, sorting, grading, wrapping, pre-cooling, and proper care taken during transportation help to reduce postharvest losses of most of the horticultural crops. Nano edible coatings available with less cost are useful for farmers in maintaining the quality of vegetables and fruits because these coatings delay respiration rate. Nanocoatings which are made with 
zinc and silver prevent the attack of microorganisms by reducing the postharvest losses. Through this edible coating and active packaging technology, the farmer can also get better prices in the market. It is also necessary that researches illuminate the precise nano-packing system on stored foodstuffs. This will allow the application of nanotechnology over a broader choice. Nanotechnology-based research will act as a novel tool for the management of postharvest losses of horticultural crops in the coming future. Besides this Nanotechnology also has a direct beneficial role for medicine and the environment. However, like all other technologies, it may have unintended effects that can adversely impact the environment, both within the human body and within the natural ecosystem. While taking advantage of this new technology for health, the environment, and sustainability benefits, science needs to examine the environmental and health implications before applying them in a broad form. Determining the toxicity of nanoparticles can be a big problem as not all engineered nanoparticles are more toxic than fine-size particles of the same chemical composition. The surface coatings of particles, exposure to UV radiation, and dispersion properties can change the behavior of the particle, which may adversely affect the environment and human health. As a result, before applying nanotechnology based technologies requires more investigations.

Acknowledgement: Authors are grateful to Medical Director, Dr. Geetika Madan Patel, Centre of Research for Development (CR4D), Parul University, Vadodara, Gujarat, India for providing the facility during the compilation of ideas in the form of the manuscript. I also thank the Director, (R\&D) and research team of CR4D, Parul University for continuous support and motivation.

Funding Statement: This research received no external funding.

Conflicts of Interest: The authors declare that they have no conflicts of interest to report regarding the present study.

\section{References}

1. Yan, C., Wang, Q., Yang, Q., Wu, W. (2020). Recent advances in aflatoxins detection based on nanomaterials. Nanomaterials, 10(9), 1626. DOI 10.3390/nano10091626.

2. Feregrino-Perez, A. A., Magaña-López, E., Guzmán, C., Esquivel, K. A. (2018). General overview of the benefits and possible negative effects of the nanotechnology in horticulture. Scientia Horticulturae, 238, 126-137. DOI 10.1016/j.scienta.2018.03.060.

3. Oerke, E. C. (2006). Crop losses to pests. The Journal of Agricultural Science, 144, 31-43. DOI 10.1017/ S0021859605005708.

4. Ladaniya, M. S. (2008). Citrus fruit. San Diego, CA, USA: Academic Press. DOI 10.1016/B978-0-12-374130-1. X5001-3.

5. Youssef, K., Roberto, S. R. (2014). Applications of salt solutions before and after harvest affect the quality and incidence of postharvest gray mold of 'Italia' table grapes. Postharvest Biology and Technology, 87, 95-102. DOI 10.1016/j.postharvbio.2013.08.011.

6. Youssef, K., Roberto, S. R. (2014). Salt strategies to control botrytismold of 'benitaka' table grapes and to maintain fruit quality during storage. Postharvest Biology and Technology, 95, 95-102. DOI 10.1016/j. postharvbio.2014.04.009.

7. Gastavsson, J., Cederberg, C., Sonesson, U. (2011). Global food losses and food waste. Rome, Italy: Food and Agriculture Organization (FAO) of the United Nations.

8. Sommer, N. F., Fortlage, R. J., Edwards, D. C. (1992). Postharvest diseases of selected commodities. In: Kader, A. A. (Ed.), Postharvest technology of horticultural crops, vol. 3311. University of California Davis Division of Agriculture and Natural Resources, and Publication, USA.

9. Baldwin, E. A., Nisperos, M. O., Chen, X., Hagenmaier, R. D. (1996). Improving storage life of cut apples and potato with edible coating. Postharvest Biology and Technology, 9, 151-163. DOI 10.1016/S0925-5214(96)00044-0. 
10. Benhamou, N. (1996). Elicitor-induced plant defence pathways. Trends Plant Science, 1, 233-240. DOI 10.1016/ 1360-1385(96)86901-9.

11. Gabler, F. M., Smilanick, J. L. (2001). Post-harvest control of table grape gray mold on detached berries with carbonate and bicarbonate salts and disinfectants. American Journal of Enology and Viticulture, 52, 12-20.

12. Romanazzi, G., Nigro, F., Ippolito, A., di Venere, D., Salerno, M. (2002). Effects of pre- and postharvest chitosan treatments to control storage greymould of table grapes. Journal of Food Science, 67, 1862-1867. DOI 10.1111/ j.1365-2621.2002.tb08737.x.

13. Liu, J., Tian, S. P., Meng, X. H., Xu, Y. (2007). Effects of chitosan on control of postharvest diseases and physiological responses of tomato fruit. Postharvest Biology and Technology, 44, 300-306. DOI 10.1016/j. postharvbio.2006.12.019.

14. Rabea, E. I., Badawy, M. E. T., Stevens, C. V., Smagghe, G., Steurbaut, W. (2003). Chitosan as antimicrobial agent: Applications and mode of action. Biomacromolecules, 4, 1457-1465. DOI 10.1021/bm034130 m.

15. Tripathi, P., Dubey, N. K. (2004). Exploitation of natural products as an alternative strategy to control postharvest fungal rotting of fruit and vegetables. Postharvest Biology and Technology, 32, 235-245. DOI 10.1016/j. postharvbio.2003.11.005.

16. Maqbool, M., Ali, A., Alderson, P. G., Zahid, N., Siddiqui, Y. (2011). Effect of a novel edible composite coating based on Gum arabic and chitosan on biochemical and physiological responses of banana fruits during cold storage. Journal of Agricultural and Food Chemistry, 59, 5474-5482. DOI 10.1021/jf200623m.

17. Pina-Barrera, A. M., Álvarez-Román, R., Báez-González, J. G., Amaya-Guerra, C. A., Rivas-Morales, C. et al. (2019). Application of a multisystem coating based on polymeric nanocapsules containing essential oil of thymus vulgaris $\mathrm{L}$. to increase the shelf life of table grapes (Vitisvinifera L.). IEEE Transactions on NanoBioscience, 18, 549-557. DOI 10.1109/TNB.2019.2941931.

18. Dean, R., van Kan, J. A., Pretorius, Z. A., Hammond-Kosack, K. E., di Pietro, A. et al. (2012). The top 10 fungal pathogens in molecular plant pathology. Molecular Plant Pathology, 13, 414-430. DOI 10.1111/j.13643703.2011.00783.x.

19. Khamis, Y., Hashim, A. (2020). Inhibitory effect of clay/Chitosan nanocomposite against penicilliumdigitatum on citrus and its possible mode of action. Jordan Journal of Biological Sciences, 13(3), 349-355 (in Press).

20. Esyanti, R. R., Zaskia, H., Amalia, A. (2019). Chitosan nanoparticle-based coating as post-harvest technology in banana. Journal of Physics: Conference Series, 1204(1), 012109. DOI 10.1088/1742-6596/1204/1/012109.

21. Qiao, G., Xiao, Z., Ding, W. (2019). Effect of chitosan/Nano-titanium dioxide/Thymol and tween films on readyto-eat cantaloupe fruit quality. Coatings, 9(12), 828. DOI 10.3390/coatings9120828.

22. Al-Naamani, L., Dutta, J., Dobretsov, S. (2018). Nanocomposite zinc oxide-chitosan coatings on polyethylene films for extending storage life of okra (Abelmoschusesculentus). Nanomaterials, 8(7), 479. DOI 10.3390/ nano8070479.

23. Song, H., Yuan, W., Jin, P., Wang, W., Wang, X. et al. (2016). Effects of chitosan/nano-silica on postharvest quality and antioxidant capacity of loquat fruit during cold storage. Postharvest Biology and Technology, 119, 41-48. DOI 10.1016/j.postharvbio.2016.04.015.

24. Youssef, K., de Oliveira, A. G., Tischer, C. A., Hussain, I., Roberto, S. R. (2019). Synergistic effect of a novel chitosan/silica nanocomposites-based formulation against graymold of table grapes and its possible mode of action. International Journal of Biological Macromolecules, 141, 247-258. DOI 10.1016/j.jbiomac.2019.08.249.

25. Bakhy, E. A., Zidan, N. S., Aboul-Anean, H. E. D. (2018). The effect of nano materials on edible coating and films' improvement. International Journal of Pharmaceutical Research and Allied Sciences, 7, 20-41.

26. Hashim, A. F., Youssef, K., Abd-Elsalam, K. A. (2019). Ecofriendly nanomaterials for controlling graymold of table grapes and maintaining postharvest quality. European Journal of Plant Pathology, 154, 377-388. DOI 10.1007/s10658-018-01662-2.

27. Dubey, P. K., Shukla, R. N., Srivastava, G., Mishra, A. A., Pandey, A. (2019). Study on quality parameters and storage stability of mango coated with developed nanocomposite edible film. International Journal of Current Microbiology and Applied Sciences, 8, 2899-2935. DOI 10.20546/ijcmas. 
28. Martinez-Ortiz, M. A., Palma-Rodriguez, H. M., Montalvo-Gonzalez, E., Sayago-Ayerdi, S. G., Utrilla-Coello, R. et al. (2019). Effect of using microencapsulated ascorbic acid in coatings based on resistant starchchayotextle on the quality of guava fruit. Scientia Horticulturae, 256, 108604. DOI 10.1016/j.scienta.2019.108604.

29. Seray, M., Skender, A., Hadj-Hamou, A. S. (2020). Kinetics and mechanisms of $\mathrm{Zn}^{2+}$ release from antimicrobial food packaging based on poly (butylene adipate-co-terephthalate) and zinc oxide nanoparticles. Polymer Bulletin, 78(2), 1021-1040. DOI 10.1007/s00289-020-03145.

30. Hernández-Hernández, H., Quiterio-Gutiérrez, T., Cadenas-Pliego, G. (2019). Impact of selenium and copper nanoparticles on yield, antioxidant system, and fruit quality of tomato plants. Plants, 8, 1-17. DOI 10.3390/ plants8100355.

31. Melo, C. B. N. F., de MendonçaSoares, B. L., Diniz, K. M., Leal, C. F., Canto, D. et al. (2018). Effects of fungal chitosan nanoparticles as eco-friendly edible coatings on the quality of postharvest table grapes. Postharvest Biology and Technology, 139, 56-66. DOI 10.1016/j.postharvbio.2018.01.014.

32. Dean, R., van Kan, J. A., Pretorius, Z. A., Hammond-Kosack, K. E., di Pietro, A. et al. (2012). The top 10 fungal pathogens in molecular plant pathology. Molecular Plant Pathology, 13, 414-430. DOI 10.1111/j.13643703.2011.00783.x.

33. Naing, A. H., Kim, C. K. (2016). Application of nano-silver particles to control the post-harvest biology of cut flowers: A review. Scientia Horticulturae, 270, 109463. DOI 10.1016/j.scienta.2020.109463.

34. Bahremand, S., Razmjoo, J., Farahmand, H. (2014). Effects of nano-silver and sucrose applicationson cut flower longevity and quality of tuberose (Polianthus tuberosa). International Journal of Horticultural Science and Technology, 1, 67-77. DOI 10.22059/IJHST.2014.50519.

35. Koohkan, F., Ahmadi, N., Ahmadi, S. J. (2014). Improving vase life of carnation cut flowers by silver nanoparticles acting as anti-ethylene agent. Journal of Applied Horticulture, 16, 210-214. DOI 10.37855/ jah.2014.v16i03.34.

36. Kazemipour, S., Hashemabadi, D., Kaviani, B. (2013). Effect of silver nanoparticles on the vase life and quality of cut chrysanthemum (Chrysanthemum morifolium L.) flower. European Journal of Experimental Botany, 3(6), 298-302.

37. Motaghayer, M., Azizi, M., Teheranifar, A. (2019). Nanosilver, salicylic acid and essential oilseffects on water relations of gerbera 'Rosalin' cut flowers. Advances in Horticultural Science, 33, 271-281. DOI 10.13128/ahs23815.

38. Kamiab, F., Shahmoradzadeh Fahreji, S., Zamani Bahramabadi, E. (2017). Antimicrobial and physiological effects of silver and silicon nanoparticles on vase life of lisianthus (Eustoma grandiflora $\mathrm{cv}$. echo) flowers. International Journal of Horticultural Science and Technology, 4(1), 135-144. DOI 10.22059/ijhst.2017.228657.180.

39. Rahman, M. M., Ahmad, S. H., Mohamed, M. T. M., Ab Rahman, M. Z. (2019). Improving the vase life of cut mokara red orchid flower using leaf extracts with silver nanoparticles. Proceedings of the National Academy of Sciences, India Section B: Biological Sciences, 89(4), 1343-1350. DOI 10.1007/s40011-018-1055-0.

40. Chhipa, H. (2019). Applications of nanotechnology in agriculture. Methods in Microbiology, 46, 115-142. DOI 10.5772/intechopen.88390.

41. Kuppusamy, P., Yousuf, M. M., Maniyam, G. P., Govindan, N. (2016). Biosynthesis of metallic nanoparticles using plant derivatives and their new avenues in pharmacological applications-An updated report. Saudi Pharmaceutical Journal, 24, 473-478. DOI 10.1016/j.jsps.2014.11.013.

42. Krishnaraj, C., Jagan, E. G., Rajasekar, S., Selvakumar, P., Kalaichelvan, P. T. et al. (2010). Synthesis of silver nanoparticles using Acalyphaindica leaf extracts and its antibacterial activity against water borne pathogens. Colloids and Surfaces B: Biointerfaces, 76, 50-56. DOI 10.1016/j.colsurfb.2009.10.008.

43. Maensiri, S., Laokul, P., Klinkaewnarong, J., Phokha, S., Promarak, V. et al. (2008). Indium oxide $\left(\operatorname{In}_{2} \mathrm{O}_{3}\right)$ nanoparticles using Aloe vera plant extract: Synthesis and optical properties. The Journal of Optoelectronics and Advanced Materials, 10, 161-165.

44. Niraimathi, K. L., Sudha, V., Lavanya, R., Brindha, P. (2013). Biosynthesis of silver nanoparticles using Alternantherasessilis (Linn.) extract and their antimicrobial, antioxidant activities. Colloids and Surfaces B: Biointerfaces, 102, 288-291. DOI 10.1016/j.colsurfb.2012.08.041. 
45. Suriyakalaa, U., Antony, J. J., Suganya, S., Siva, D., Sukirtha, R. et al. (2013). Hepatocurative activity of biosynthesized silver nanoparticles fabricated using andrographispaniculata. Colloids and Surfaces B: Biointerfaces, 102, 189-194. DOI 10.1016/j.colsurfb.2012.06.039.

46. Kora, A. J., Rao, B. S., Arunachalam, J. (2012). Aqueous extract of gum olibanum (Boswelliaserrata): A reductant and stabilizer for the biosynthesis of antibacterial silver nanoparticles. Process Biochemistry, 47, 1516-1520. DOI 10.1016/j.procbio.2012.06.004.

47. Jain, D., Kumar Daima, H., Kachhwaha, S., Kothari, S. L. (2009). Synthesis of plant-mediated silver nanoparticles using papaya fruit extract and evaluation of their anti-microbial activities. Digest Journal of Nanomaterials and Biostructures, 4, 557-563.

48. Daisy, P., Saipriya, K. (2012). Biochemical analysis of Cassia fistula aqueous extract and phytochemically synthesized gold nanoparticles as hypoglycemic treatment for diabetes mellitus. International Journal of Nanomedicine, 7, 1189. DOI 10.2147/2FIJN.S26650.

49. Sathishkumar, M., Sneha, K., Won, S. W., Cho, C. W., Kim, S. et al. (2009). Cinnamon zeylanicum bark extract and powder mediated green synthesis of nano-crystalline silver particles and its bactericidal activity. Colloids and Surfaces B: Biointerfaces, 73, 332-338. DOI 10.1016/j.colsurfb.2009.06.005.

50. Satyavani, K., Gurudeeban, S., Ramanathan, T., Balasubramanian, T. (2011). Biomedical potential of silver nanoparticles synthesized from calli cells of citrulluscolocynthis (L.) schrad. Journal of Nanobiotechnology, 9, $1-8$. DOI 10.1186/1477-3155-9-43.

51. Kaviya, S., Santhanalakshmi, J., Viswanathan, B., Muthumary, J., Srinivasan, K. (2011). Biosynthesis of silver nanoparticles using Citrus sinensis peel extract and its antibacterial activity. Spectrochimica Acta Part A: Molecular and Biomolecular Spectroscopy, 79, 594-598. DOI 10.1016/j.saa.2011.03.040.

52. Singh, S., Saikia, J. P., Buragohain, A. K. (2013). A novel 'green' synthesis of colloidal silver nanoparticles (SNP) using dilleniaindica fruit extract. Colloids and Surfaces B: Biointerfaces, 102, 83-85. DOI 10.1016/j. colsurfb.2012.08.012.

53. Ghosh, S., Patil, S., Ahire, M., Kitture, R., Kale, S. et al. (2012). Synthesis of silver nanoparticles using dioscoreabulbifera tuber extract and evaluation of its synergistic potential in combination with antimicrobial agents. International Journal of Nanomedicine, 7, 483. DOI 10.2147/2FIJN.S24793.

54. Zahir, A. A., Abdul Rahuman, A. (2012). Evaluation of different extracts and synthesised silver nanoparticles from leaves of Euphorbia prostrata against Haemaphysalisbispinosa and Hippoboscamaculata. Veterinary Parasitology, 187, 511-520. DOI 10.1016/j.vetpar.2012.02.001.

55. Cruz, D., Falé, P. L., Mourato, A., Vaz, P. D., Serralheiro, M. L. et al. (2010). Preparation and physicochemical characterization of $\mathrm{Ag}$ nanoparticles biosynthesized by Lippia citriodora (Lemon verbena). Colloids and Surfaces B: Biointerfaces, 81(1), 67-73. DOI 10.1016/j.colsurfb.2010.06.025.

56. MubarakAli, D., Thajuddin, N., Jeganathan, K., Gunasekaran, M. (2011). Plant extract mediated synthesis of silver and gold nanoparticles and its antibacterial activity against clinically isolated pathogens. Colloids and Surfaces B: Biointerfaces, 85(2), 360-365. DOI 10.1016/j.colsurfb.2011.03.009.

57. Vankar, P. S., Bajpai, D. (2010). Preparation of gold nanoparticles from mirabilis jalapaflowers. Indian Journal of Biochemistry \& Biophysics, 47, 157-160.

58. Das, S., Das, J., Samadder, A., Bhattacharyya, S. S., Das, D. et al. (2013). Biosynthesized silver nanoparticles by ethanolic extracts of phytolaccadecandra, gelsemiumsempervirens, hydrastiscanadensis and thujaoccidentalis induce differential cytotoxicity through G2/M arrest in a375 cells. Colloids and Surfaces B: Biointerfaces, 101, 325-336. DOI 10.1016/j.colsurfb.2012.07.008.

59. Dipankar, C., Murugan, S. (2012). The green synthesis, characterization and evaluation of the biological activities of silver nanoparticles synthesized from iresineherbstii leaf aqueous extracts. Colloids and Surfaces B: Biointerfaces, 98, 112-119. DOI 10.1016/j.colsurfb.2012.04.006.

60. Sukirtha, R., Priyanka, K. M., Antony, J. J., Kamalakkannan, S., Thangam, R. et al. (2012). Cytotoxic effect of green synthesized silver nanoparticles using Melia azedarach against in vitro heLa cell lines and lymphoma mice model. Process Biochemistry, 47(2), 273-279. DOI 10.1016/j.procbio.2011.11.003. 
61. Jayaseelan, C., Abdul, A., Govindasamy, R., Arivarasan, V. K., Santhoshkumar, T. et al. (2011). Synthesis of pediculocidal and larvicidal silver nanoparticles by leaf extract from heartleaf moonseed plant, Tinospora cordifolia Miers. Parasitology Research, 109(1), 185-194. DOI 10.1007/s00436-010-2242-y.

62. Aromal, S. A., Philip, D. (2012). Green synthesis of gold nanoparticles using Trigonella foenum-graecum and its size-dependent catalytic activity. Spectrochimica Acta Part A: Molecular and Biomolecular Spectroscopy, 97, 1-5. DOI 10.1016/j.saa.2012.05.083.

63. Nagati, V. B., Alwala, J., Koyyati, R., Donda, M. R., Banala, R. et al. (2012). Green synthesis of plant-mediated silver nanoparticles using Withania somnifera leaf extract and evaluation of their antimicrobial activity. Asian Pacific Journal of Tropical Biomedicine, 2, 1-5.

64. Maity, T. R., Samanta, A., Saha, B., Datta, S. (2019). Evaluation of Piper betle mediated silver nanoparticle in post-harvest physiology in relation to vase life of cut spike of gladiolus. Bulletin of the National Research Centre, 43(1), 1-11. DOI 10.1186/s42269-019-0051-8.

65. Solgi, M. (2014). Evaluation of plant-mediated silver nanoparticles synthesis and its application in postharvest physiology of cut flowers. Physiology and Molecular Biology of Plants, 20(3), 279-285. DOI 10.1007/s12298014-0237-3.

66. Solgi, M. (2018). The application of new environmentally friendly compounds on postharvest characteristics of cut carnation (Dianthus caryophyllus L.). Brazilian Journal of Botany, 41(3), 515-522. DOI 10.1007/s40415-0180464-x.

67. Carrillo-López, L. M., Morgado-González, A., Morgado-González, A. (2016). Biosynthesized silver nanoparticles used in preservative solutions for Chrysanthemum cv. Puma, Journal of Nanomaterials, 1-10. DOI 10.1155/2016/ 1769250.

68. Solgi, M., Kafi, M., Taghavi, T., Naderi, R. (2009). Essential oils and silver nanoparticles (SNP) as novel agents to extend vase-life of gerbera (Gerbera jamesonii cv. 'Dune') flowers. Postharvest Biology and Technology, 53(3), 155-158. DOI 10.1016/j.postharvbio.2009.04.003.

69. Anfossi, L., Baggiani, C., Giovannoli, C., Giraudi, G. (2013). Lateral flow immunassays for alfatoxins $B$ and $G$ for alfatoxin M1, pp. 315-339. Aflatoxins-Recent Adv. Future Prospect.

70. Greiner, R., Oehlke, K., Yada, R. (2009). Current and projected Applications of Nanomaterials in the Food Sector. https://worldfoodscience.com/article/current-and-projectedapplications-nanomaterials-food-sector.

71. Sujithra, S., Manikkandan, T. R. (2019). Application of nanotechnology in packaging of foods: A review. International Journal of ChemTech Research, 12, 7-14. DOI 10.20902/IJCTR.2019.120402.

72. Yang, F. M., Li, H. M., Li, F., Xin, Z. H., Zhao, L. Y. et al. (2010). Effect of nano-packing on preservation quality of fresh strawberry (Fragaria ananassa Duch Cv Fengxiang) during storage at $4^{\circ} \mathrm{C}$, Journal of Food Science, $75(3)$, C236-C240. DOI 10.1111/j.1750-3841.2010.01520.x.

73. Bodbodak, S., Rafiee, Z. (2016). Recent trends in active packaging in fruits and vegetables. Eco-friendly technology for post-harvest produce quality, pp. 77-125. Academic Press. DOI 10.1016/B978-0-12-8043134.00003-7.

74. Li, H., Feng, L., Wang, L., Sheng, G., Xin, Z. et al. (2009). Effect of nano-packing on preservation quality of Chinese jujube (Ziziphusjujuba mill. var. inermis (Bunge) rehd). Food Chemistry, 114, 547-552. DOI 10.1016/ j.foodchem.2008.09.085.

75. Hu, A. W., Fu, Z. H. (2003). Nano technology and its application in packaging and packaging machinery. Packaging Engineering, 24, 22-24. DOI 10.1007/978-3-319-39303-2_6.

76. https://www.foodsafetywatch.org/research/nanotechnology-helps-prevent-biofilms/.

77. Zhang, X., Xiao, G., Wang, Y. (2017). Preparation of chitosan- $\mathrm{TiO}_{2}$ composite film with efficient antimicrobial activities under visible light for food packaging applications. Carbohydrate Polymer, 169, 101-107. DOI 10.1016/j.carbpol.2017.03.073.

78. Gu, R., Yun, H., Chen, L. (2020). Regenerated cellulose films with amino-terminated hyper branchedpolyamic anchored nanosilver for active food packaging. ACS Applied Bio Materials, 3, 602-610. DOI 10.1021/ acsabm.9b00992. 
79. Zhu, Z., Zhang, Y., Zhang, Y. (2019). Preparation of $\mathrm{TiO}_{2}$ nanofibers for fruit packaging materials with efficient photocatalytic degradation of ethylene. Materials (Basel), 16, 896. DOI 10.3390/ma12060896.

80. Yadav, S., Mehrotra, G. K., Dutta, P. K. (2021). Chitosan based ZnO nanoparticles loaded gallic-acid films for active food packaging. Food Chemistry, 334, 127605. DOI 10.1016/j.foodchem.2020.127605.

81. Pérez-Moreno, A., Fabián, F. L., Hermes, P. H., Edgar, V. N., Ileana, V. R. et al. (2021). Nanoscience and nanotechnology regarding food packaging and nanomaterials to extending the postharvest life and the shelf life of foods. Food losses, sustainable postharvest and food technologies, pp. 313-384. Academic Press. DOI 10.1016/B978-0-12-821912-6.00001-8.

82. Rhim, J. W. (2004). Increase in water vapor barrier property of biopolymer-based edible films and coatings by compositing with lipid materials. Food Science and Biotechnology, 13, 528-535.

83. Ravichandran, R. (2010). Nanotechnology applications in food and food processing: Innovative green approaches, opportunities and uncertainties for global market. International Journal of Green Nanotechnology: Physics and Chemistry, 1(2), 72-96. DOI 10.1080/19430871003684440.

84. Zambrano-Zaragoza, M. L., Gutiérrez-Cortez, E., Del Real, A., González-Reza, R. M., Galindo-Pérez, M. J. et al. (2014). Fresh-cut red delicious apples coating using tocopherol/mucilage nanoemulsion: Effect of coating on polyphenol oxidase and pectin methylesterase activities. Food Research International, 62, 974-983. DOI 10.1016/j.foodres.2014.05.011.

85. Gardesh, A. S. K., Badii, F., Hashemi, M., Ardakani, A. Y., Maftoonazad, N. et al. (2016). Effect of nanochitosan based coating on climacteric behavior and postharvest shelf-life extension of apple cv. GolabKohanz. LWT, 70, 3340. DOI 10.1016/j.lwt.2016.02.002.

86. Adnan, A., Mohammad, R., Farhan, J. A., Zeenat, I., Roop, K. K. et al. (2009). Nanoemulsion components screening and selection: A technical note. AAPS PharmSciTech, 10, 69-76. DOI10.1208/s12249-008-9178-x.

87. Zahid, N., Ali, A., Manickam, S., Siddiqui, Y., Maqbool, M. (2012). Potential of chitosan-loaded nanoemulsions to control different Colletotrichum spp. and maintain quality of tropical fruits during cold storage. Journal of Applied Microbiology, 113(4), 925-939. DOI 10.1111/j.1365-2672.2012.05398.x.

88. Ohashi, T. L., Pilon, L., Spricigo, P. C., Miranda, M., Corrêa, D. S. et al. (2015). Postharvest quality of 'golden' Papayas (Carica papaya L.) coated with carnauba wax nanoemulsions. Revista Iberoamericana de Tecnología Postcosecha, 16(2), 199-209.

89. Charych, D., Cheng, Q., Reichert, A., Kuziemko, G., Stroh, N. et al. (1996). A 'litmus test' for molecular recognition using artificial membranes. Chemistry \& Biology, 3, 113-120. DOI 10.1016/S1074-5521(96)90287-2.

90. Yadollahi, A., Arzani, K., Khoshghalb, H. (2009). The role of nanotechnology in horticultural crops postharvest management. Southeast Asia Symposium on Quality and Safety of Fresh and Fresh-Cut Produce. ISHS ActaHorticulturae, 875, 49-56. DOI 10.17660/ActaHortic.2010.875.4.

91. Imafidon, G. I., Spanier, A. M. (1994). Unraveling the secret of meat flavor. Trends in Food Science \& Technology, 5, 315-321. DOI 10.1016/0924-2244(94)90182-1.

92. Haruyama, T. (2003). Micro- and nanobiotechnology for biosensing cellular responses. Advance Drug Delivery Review, 55, 393-401. DOI 10.1016/s0169-409x(02)00224-7.

93. Lawrence, M. J., Rees, G. D. (2000). Microemulsion-based media as novel drug delivery systems. Advance Drug Delivery Review, 45, 89-121. DOI 10.1016/S0169-409X(00)00103-4.

94. Delfino, J. R., da Silva, J. L., Marques, A. L. B., Stradiotto, N. R. (2020). Antioxidants detection in aviation biokerosene by high-performance liquid chromatography using gold nanoparticles anchored in reduced graphene oxide. Fuel, 260, 116315. DOI 10.1016/j.fuel.2019.116315.

95. Fakayode, S. O., Baker, G. A., Bwambok, D. K., Bhawawet, N., Elzey, B. et al. (2020). Molecular (Raman, NIR, and FTIR) spectroscopy and multivariate analysis in consumable products analysis1. Applied Spectroscopy Reviews, 55(8), 647-723. DOI 10.1080/05704928.2019.1631176.

96. Naser-Sadrabadi, A., Zare, H. R., Benvidi, A. (2020). Photochemical deposition of palladium nanoparticles on $\mathrm{TiO}_{2}$ nanoparticles and their application for electrocatalytic measurement of nitrate ions in potato, onion and cabbage using bipolar electrochemical method. Measurement, 166, 108222. DOI 10.1016/j.measurement.2020.108222. 
97. Madhusudhana, M. G., Bhakta, A. K. (2020). Bismuth-nanoparticles decorated multi-wall-carbon-nanotubes cast-coated on carbon paste electrode; an electrochemical sensor for sensitive determination of gallic acid at neutral pH. Materials Science for Energy Technologies, 3, 174-182. DOI 10.1016/j.mset.2019.10.001.

98. Ye, Y., Ji, J., Sun, Z. (2020). Recent advances in electrochemical biosensors for antioxidant analysis in foodstuff. TrAC Trends in Analytical Chemistry, 122, 115718. DOI 10.1016/j.trac.2019.115718.

99. Mukhopadhyay Siddhartha, S. (2014). Nanotechnology in agriculture prospects and constraints. Nanotechnology in Agriculture Prospects and Constraints, 7, 63-71. DOI 10.2147/NSA.S39409.

100. Parisi, C., Vigani, M., Rodriguez-Cerezo, E. (2014). Proceedings of workshop on "Nanotechnology for the agricultural sector: From research to the field". JRC Working Papers JRC89736. Joint Research Centre (Seville site). DOI 10.2791/80497. 